\title{
Communications
}

\section{Synthesis and Antibacterial Activity of 1,8-Naphthyridine Cephalosporins}

\author{
Jong-Kyu Park, Sun-Kwon Im, Hyun Ju, Jae-Man Jeon, Chun-Gyu Kim, \\ Dong-Uk Kim, Jin-Cheol Yoo, ${ }^{\dagger}$ Seung-Sik Cho, and Sung-Ki Cho ${ }^{*}$

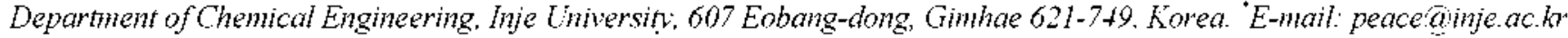
${ }^{\dagger}$ Department of Pharmacy. Chosum Unversitv, 375 Seoseok-dong. Dong-gu. Gwangju 501-759. Korea Received October 29.2004
\end{abstract}

Key Words : Cephalosporins, $\beta$-Lactam. Antibiotics. Naphthy ridine

Many of the introduced cephalosporins have a common structural figure. They have a $7 \beta-[(Z)-2-(2$-aminothiazole-4yl)-2-alkoxyiminoacetamido] side chain at $\mathrm{C}-7 \times$ position and have monocyclic or bicyclic nitrogen-containing heterocycles at $\mathrm{C}-3^{\prime}$ position.

Recently. C-3' quaternary ammonium cephalosporins such as cepirome (CPR). ${ }^{1}$ ceftazidime (CAZ) and cefepime $(\mathrm{CEPM})^{-}$have shown increased activities against both Grampositive bacteria and Gram-negative bacteria including Psudomonas aeniginosa. ${ }^{3}$

Therefore our efforts have been focused on syinthesizing C-3. quaternary anmonium cephalosporins with more enhanced antibacterial activities and better pharmacokinetic profiles than "third-generation" antibacterial agents

We are interested in substitution at the C-3' position with nitrogen-containing heterocyclic compounds. 1.8-naphthyridine 2 so we have prepared 1.8-naphthyridine derivatives and a new series of quaternized cephalosporins. In this paper. we wish to describe the sy'nthesis and antibacterial activity of the novel series of cephalosporins having 1.8naphthyridine moiety at $\mathrm{C}^{\circ} 3^{\circ}$ side chain.
2.3-Disubstituted 1.8-naphthyridine derivatives. 2a-2h. were prepared either directly by Friedländer reactions. 2aminonicotinaldehyde with $\alpha$-methylene compounds using piperidine as catalyst. ${ }^{+6}$ or by subsequent reactions of the bicyclic products.

The quaternary anmonium cephalosporins. $7 \beta-[(Z)-2-(2-$ aminothiazole-4-yl)-2-methoxyiminoacetamido]-3-[8-(2.3disubsitituted)-1 8-naphthyridiniummethỵl]-3-cephen-4carboxylic acid inner salt. $\mathbf{3 a}-\mathbf{3 h}$. were prepared according to the general method as shown in Scheme $1{ }^{7.8}$ The silylation of cefotaxime (CTX) 1 was carried out with $N$-methyl- $N$ (trimethylsilyl)trifluoroacetamide (MSTFA) in methylene chloride followed by in sint formation of the C-3' iodide with trimethylsilyl iodide (TMSI). The silylated iodo compounds were quaternized with 1.8 -naphthỵridine 2 , to give products.

The final products. $3 \mathrm{a}-3 \mathrm{~h}$. were purified by column chromatography using $75 \%$ aqueous acetonitrile solution

The in vitro antibacterial activities (MIC. $\mu \mathrm{g} / \mathrm{mL}$ ) of the new cephalosporins. $3 \mathrm{a}-3 \mathrm{~h}$. which are against Gram-positive and Gram-negative bacteria were determined by the

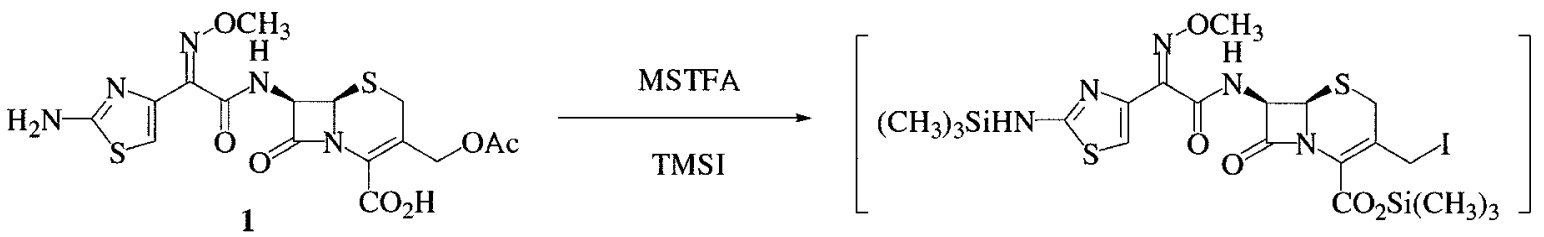

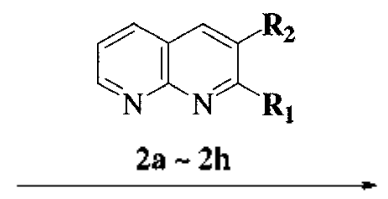

BSA<smiles>[R2]c1cc2ccc[n+](CC3=C(C(=O)[O-])N4C(=O)C(NC(=O)/C(=N/OC)c5csc(N)n5)CSC34)c2nc1[R2]</smiles>

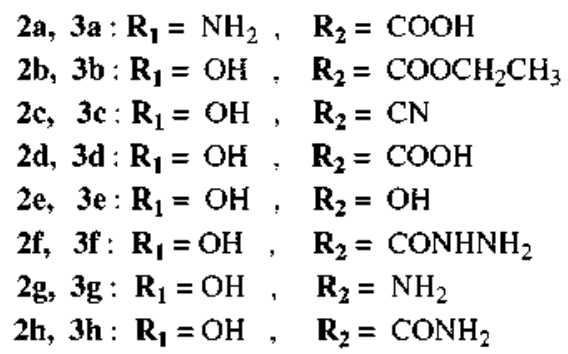

Scheme 1. Synthesis of quatemized cephalosporins. Abbreviations: MSTFA, N-(methyl)- $k$-(trimethylsilyl lutrifluoroacetamide; TMSI, trimethylsilyl iodide: BSA, $\mathrm{N}, \mathrm{O}$-bis(trimethylsilyl)acetamide. 
Table 1. In vitro antibacterial activity of the cephalosporins. (3a-3h)

\begin{tabular}{|c|c|c|c|c|c|c|c|c|c|}
\hline \multirow{2}{*}{ Compound } & \multicolumn{9}{|c|}{$\operatorname{MIC}(\mu \mathrm{g} / \mathrm{mL})$} \\
\hline & Sa.t & S.a.2 & $S . p$ & S.t. & E.C.I & E.c.2 & Pal & Pa.2 & Ko. \\
\hline $3 \mathrm{a}$ & 1.25 & 0.019 & 0.019 & 0.039 & 0.039 & 0.075 & 0.075 & 0.039 & 0.019 \\
\hline $3 b$ & 5 & 0.075 & 0.019 & 0.313 & 0.156 & 0.313 & 0.313 & 0.039 & 0.019 \\
\hline $3 c$ & 2.5 & 0.075 & 0.039 & 0.625 & 0.313 & 0.625 & 0.625 & 0.039 & 0.019 \\
\hline $3 d$ & 2.5 & 0.075 & 0.039 & 0.156 & 0.039 & 0.156 & 0.156 & 0.039 & 0.039 \\
\hline $3 e$ & 5 & 0.019 & 0.019 & 0.075 & 0.019 & 0.075 & 0.313 & 0.039 & 0.019 \\
\hline $3 \mathrm{f}$ & 2.5 & 0.019 & 0.019 & 5 & 0.019 & 0.313 & 0.313 & 0.156 & 0.039 \\
\hline $3 g$ & 2.5 & 0.019 & 0.019 & 0.625 & 0.039 & 0.075 & 0.313 & 0.156 & 0.019 \\
\hline $3 \mathbf{h}$ & 2.5 & 0.019 & 0.019 & 2.5 & 0.625 & 0.156 & 0.313 & 0.156 & 0.075 \\
\hline CAZ & 5 & 2.5 & 0.313 & 0.313 & 0.156 & 0.313 & 0.039 & 0.019 & 0.019 \\
\hline CTX & 1.25 & 0.019 & 0.019 & 0.039 & 0.039 & 0.075 & 0.075 & 0.039 & 0.019 \\
\hline
\end{tabular}

Abbreviations: S.a.1, Staphlococcus atmens KCTC 1928; S.a.2. Staphlococens antens subsp. anmes ATCC 6538P. S.p., Streptococchs purogens ATCC 21059; S.t. Samonella nphimuitum KCTC 1925; E.c.1. Escherichia coli ATCC 9637: E.c. 2. Escherichia coli KCTC 1923: Pa.1. Psendomonas aeruginosa ATCC 15692: P.a.2. Psendomonas aeruginosa ATCC 27853: Ko. Klepsistla orytoca ATCC 8724: CAZ. ceftazidime: CTX. cefotaxime.

Mueller-Hinton-agar dilution method. ${ }^{\text {?ti }}$ The results of MIC test are summarized in Table 1 and it includes those of ceftazidime and cefotaxime for comparison, as well.

Most of the compounds, $\mathbf{3 a - 3 h}$, were superior to ceftazidime and comparable to cefotaxime in antibacterial activity against selected Grant-positive bacteria and Gram-negative bacteria. However. They were less active than ceftazidime against Psettomonas aeniginosa ATCC 15692 and Psetdomonas aeniginosa ATCC 27853.

Especially the product 3a possessing 2-amino-1,8-11aphthyridine-3-carboxylic acid group showed the best activity against Gram-positive and Gram-negative bacteria and its activity was equal to cefotaxime.

In conclusion, $7 \beta$-[(Z)-2-(2-aminothiazole-4-yl)-2-methoxyiminoacetamido]-3-[8-(2.3-disubsitituted)-1.8-naphthyridiniummethyl]-3-cephem-4-carboxylic acid inner salt. 3a-3h. showed a well-balanced antibacterial spectrum and potent activities against Gram-positive and Gram-negative bacteria. Further studies in this series will be focused on modifying their structure with a broad spectrum of antibacterial activities.

\section{References}

1. Lattrell. R: Blumbach. J:: Duerchheimer. W: Fehlhaber. H. M: Fleischunanu. K: Kirrstetter, R: Menke. B.: Schemnemann. K. H.: Schrinter, E.: Schwab. W.: Seeger. K.: Seebert, G.: Wieduwlt. M. J. Ambibiotics 1988, $11,1374$.

2. Naito. T.: Aburaki. S.: Kamachi. H.: Narita. Y. J. Antibiotics 1986. 39. 1092.

3. Ohki. H.: Kawabata. K: Okuda. S.: Kamimura. T.: Skane. K. J. Antibiotics 1995, 18.1049

4. Edward, M. H.: Denins, K. J. G. J. Heterocylic Chem 1974, 11. 151

5. Dennis. K. J. G.: Edward. M. H. J. Aedicinal Chentistry 1977. 20.
124.

6. Edward, M. H.: Dennis. K. J. G. J. Medicinal Chemistry 1973, 16. 849 .

7. General procedure for 3a. Cefotaxime (CTX) 1 (500 min. 1.1 mmol) was suspended in methylene chloride $(10 \mathrm{~mL})$ under nitrogen atmosphere. $\mathrm{N}$-Methyl- $\mathrm{K}$-(trimethylsilyl) trifluoroacetamide ( $0.8 \mathrm{~mL}, 4 \mathrm{mmol}$ ) was added and the mixture was stirred for 1 hour. The resulting homogeneous solution of cephem trimethylsilyl ester was cooled to $0^{\circ} \mathrm{C}$ and trimethylsilyliodide $(0.75 \mathrm{~mL} .4 .4 \mathrm{mmol}$ ) was added. The solution was stirred for 30 minutes and then evaporated in vacto to afford the 3-iodomethyl cephem as a viscous oil. The oily residue was dissolved in acetonitrile $(10 \mathrm{~mL})$ and tetrahydrofuran $(2 \mathrm{~mL})$. The stirred solution was added, in one portion. to a solution of 2-amino-1.8naphthyridine-3-carboxylic acid 2a (196 mo. $1.1 \mathrm{mmol}$ ) silylated with $\mathrm{N} O$-bis-(trimethylsilyl)acetamide ( $1.05 \mathrm{~mL} .3 .3 \mathrm{mmol}$ ) in acetonitrile $(10 \mathrm{~mL})$. The reaction mixture was stirred for 3 hours at room temperature and then added to a minture of methanol (l $\mathrm{mL}$ ) and acetonitrile $(2 \mathrm{~mL})$ at $0^{\circ} \mathrm{C}$. The mixture was stirred at 0 ${ }^{\circ} \mathrm{C}$ for 30 minutes. The precipitated solids were collected by filteration to provide a solid product. Water $(10 \mathrm{~mL})$ was added to the solid. and the misture was neutralized with saturated sodium bicarbonate solution and then concentrated. The residue was purified by column chromatography (eluent : $\mathrm{CH}_{3} \mathrm{CN} \mathrm{H}_{2} \mathrm{O}=4: 1$ ) over silica gel to give $3 \mathrm{a}$ in $43^{\circ} \%$ vield.

${ }^{1} \mathrm{H}-\mathrm{NMR}\left(300 \mathrm{MHz}\right.$. DMSO- $\left.d_{6}\right) \delta=6.66(1 \mathrm{H}, \mathrm{s}) .6 .04(1 \mathrm{H}, \mathrm{d})$. $5.80(1 \mathrm{H} . \mathrm{q}) .5 .36-5.01$ (2H. ABq) $9.11-8.88$ (4H. m). $9.59(1 \mathrm{H}$. d. $J=8.1 \mathrm{~Hz}$ ). 7.22 (2H. s). 3.75 (lH. s): '? $\mathrm{C}-\mathrm{NMR}$ (300 MHz. DMSO- $\left.d_{6}\right) \delta=165.7 .165 .1$. 162.9. 162.2. 159.6. 158.7. 155.3. 146.9. 142.7. 140.65. 139.9. 136.7. 135.3. 127.9. 119.1. 114.1. $110.6,110.1,108.1,57.6 .54 .0 .52 .2 \mathrm{IR}(\mathrm{KBr}) 3350,1733.1676$. $1635 \mathrm{~cm}^{-1}$, HRMS (FAB) Calcd for $\mathrm{C}_{23} \mathrm{H}_{21} \mathrm{~N}_{8} \mathrm{O}_{7} \mathrm{~S}_{2}: 585.0975$. Found 585.0996 .

8. Bonjouklian. R.: Phillips. M. L. Tetrahedron Lett. 1981. 22. 3915.

9. Craig. W. A.: Sul. B. Antibiotics in Laboratory Medicine. 2nd Ed: Williams \& Wilkins: USA. 1986; p 477

10. Leiner. F.: Misiek. M. Pursiano. T. A.: Buck, R. E.; Chisholm. D. R.; Deregis. R. G.: Tsai. Y. H.: Price, K. E. Amimicrob. Agents Chentother: 1976. 10. 426 . 